$\xi=-1$

\title{
Milk Productivity of Black-Motley Cows with Easy and Troubled Calvings
}

\author{
Feyzullah Ramazanovich Feyzullayev*1, Vadim Anatolyevich Babushkin'1, Anatoly Vladimirovich Bakai', Tatiana \\ Viktorovna Lepekhina ${ }^{1}$
}

${ }^{1}$ Michurinsk State Agrarian University, 393760, Internatsional'naya st., 101, Michurinsk, Tambovsk region, Russia

*Corresponding author E-mail: ffejzullaev@inbox.ru

\begin{abstract}
During its formation and improvement, cattle acquired a number of biological and economic-useful qualities, which allowed identifying separate groups of animals with high productivity and productive longevity. One of the main criteria for cow selection for further breeding is the quantity and quality of dairy products [4]. Profitability of dairy farming largely depends on both milk yield and the reproductive ability of cows. Troubled calving and subsequent diseases and complications affect the state of the animal organism; preservation and restoration of the health of a cow after troubled calving require considerable expenses. This research was aimed at examining milk production in cows with easy and troubled calving. To achieve this goal, in the studied number of cows with easy and troubled calving, the authors analyzed the following parameters: milk yield during the first lactation, fat and protein mass fraction, the amount of milk fat and milk protein; milk productivity was also studied, depending on the age at first insemination and the duration of the service period. It has been found that milk yields in the cows with troubled calving were higher than in the cows with easy calving. The influence of the age at the first fruitful insemination on the further milk productivity has been determined: the highest yields were obtained from the cows with the age at the first fruitful insemination in the interval between 15.1 and 17.0 months. The maximum milk yields during the first lactation $-6,206 \mathrm{~kg}$ - were observed in the cows with relatively short service period (61 to 90 days).
\end{abstract}

Keywords: Motley breed, milk productivity, milk yield per lactation, the mass fraction of fat, the mass fraction of protein, easy calving, troubled calving

\section{Introduction}

One of the main criteria for choosing cows for further breeding is the quantity and the quality of dairy products [4]. Profitability of dairy farming largely depends on both milk yield and the reproductive ability of cows. Troubled calving and subsequent diseases and complications affect the state of animals' organism; preservation and restoration of the health of a cow after troubled calving require considerable expenses [1].

\section{Conditions and methods}

The research was performed based on the data of pedigree and zootechnical accounting with the black-motley cows at JSC SF Povadino in the Moscow region. To determine the effect of the ease of calving on future milk productivity in cows, the following groups were formed: the first group included cows with easy calving $(n=261)$, the second group included cows with troubled calving and cases of stillbirth ( $\mathrm{n}=97)$.

\section{Results and discussion}

In assessing the productive qualities, a special place is taken by the amount of milk yield per first lactation (Table 1). It has been found that it was higher in the cows with troubled calving (group II) $-5,904 \mathrm{~kg}$, which was significantly higher than in the cows of the first group $-5,385 \mathrm{~kg}$, the difference being $519 \mathrm{~kg}(\mathrm{P}>0.99)$. The mass fraction of fat in the milk from cows from different groups was equal, no significant differences had been determined, same as no differences had been found in the mass fraction of protein.

Table 1: Milk yield in the cows during the first lactation

\begin{tabular}{|c|c|c|c|c|c|}
\hline Group & Milk yield, $\mathrm{kg}$ & Mass fraction of fat, $\%$ & Amount of milk fat, $\mathrm{kg}$ & $\begin{array}{l}\text { Mass fraction } \\
\text { of protein, } \%\end{array}$ & $\begin{array}{l}\text { Amount of } \\
\text { milk protein, } \mathrm{kg}\end{array}$ \\
\hline $\begin{array}{l}\mathrm{I}=261) \\
(\mathrm{n}=1\end{array}$ & $5,385 \pm 90 * *$ & $3.86 \pm 0.02$ & $207 \pm 4 * *$ & $2.96 \pm 0.01$ & $159 \pm 3$ \\
\hline $\begin{array}{l}\text { II } \\
(\mathrm{n}=97)\end{array}$ & $5,904 \pm 152 * *$ & $3.83 \pm 0.04$ & $226 \pm 7 * *$ & $2.96 \pm 0.02$ & $174 \pm 5$ \\
\hline
\end{tabular}

At the same time, the calculated data show that in terms of the amount of milk fat (207 kg vs $226 \mathrm{~kg}$ ) and the amount of milk protein $(174 \mathrm{~kg}$ vs $159 \mathrm{~kg})(\mathrm{P}>0.99)$, the cows from the second group with troubled calving were veraciously superior to those of the first group, which could be explained by higher milk yield per lactation. 
With the intensification of animal husbandry, it is important to reduce the period of cows' growing [5]. The special factor that influences future milk production is the age at the first fruitful insemination $[2,3]$.

Assessing the effect of reproductive functions on milk production, the number of cows was distributed in the following way: the first subgroup included the cows with the ages at fruitful insemination of up to 15 months (the group of cows with troubled calving did not include the animals with early age at fruitful insemination); the second subgroup included the cows with the ages from 15.1 to 17.0 months; the third subgroup - from 17.1 to 19.0 months, the fourth subgroup - from 19.1 to 21.0 months, and the fifth subgroup included those inseminated at the age of over 21.1 months.

Analysis of the research results has revealed some differences in the economic characteristics (Table 2).

The highest milk productivity was detected in the cows with the age at the first fruitful insemination from 15.1 to 17.0 months. In terms of the milk yield, they surpassed the cows both with early age of the first fruitful insemination (up to 15.0 months) and those with the older age. It should be noted that milk yields in the cows with troubled calving, the age of which at the first fruitful insemination ranged from 15.1 to 17.0 months, were higher by $769 \mathrm{~kg}$ $(\mathrm{P}>0.95)$ than in the cows with easy calving in the same subgroup.

Table 2: Milk yield in the cows with various ages at the first fruitful insemination

\begin{tabular}{|c|c|c|c|c|c|c|}
\hline \multirow{2}{*}{$\begin{array}{l}\text { The age of the first } \\
\text { fruitful insemination, } \\
\text { months. }\end{array}$} & \multirow[b]{2}{*}{ Group } & \multicolumn{4}{|c|}{ Milk yield for 305 days of the first lactation } & \multirow[b]{2}{*}{$\begin{array}{l}\text { amount of milk protein, } \\
\mathrm{kg}\end{array}$} \\
\hline & & milk yield, kg & $\begin{array}{l}\text { mass fraction of } \\
\text { fat, } \%\end{array}$ & $\begin{array}{l}\text { amount of milk } \\
\text { fat, } \mathrm{kg}\end{array}$ & $\begin{array}{l}\text { mass fraction of } \\
\text { protein, } \%\end{array}$ & \\
\hline \multirow{2}{*}{$<15$} & $\mathrm{I}(\mathrm{n}=14)$ & $5,625 \pm 342$ & $4.06 \pm 0.07$ & $229 \pm 15$ & $2.95 \pm 0.04$ & $167 \pm 11$ \\
\hline & II $(n=0)$ & - & - & - & - & - \\
\hline \multirow{2}{*}{$15.1-17.0$} & $\mathrm{I}(\mathrm{n}=51)$ & $5,639 \pm 192 * * *$ & $3.87 \pm 0.05$ & $218 \pm 8$ & $2.92 \pm 0.03$ & $165 \pm 6$ \\
\hline & II $(n=12)$ & $6,408 \pm 306 * * *$ & $4.01 \pm 0.10$ & $257 \pm 14$ & $2.91 \pm 0.08$ & $187 \pm 11$ \\
\hline \multirow{2}{*}{$17.1-19.0$} & $\mathrm{I}(\mathrm{n}=100)$ & $5,539 \pm 156$ & $3.87 \pm 0.04$ & $215 \pm 7$ & $2.97 \pm 0.02$ & $166 \pm 5$ \\
\hline & II $(n=39)$ & $5,973 \pm 236$ & $3.75 \pm 0.06$ & $224 \pm 9$ & $2.96 \pm 0.04$ & $177 \pm 7$ \\
\hline $19.1-21.0$ & II $(n=29)$ & $5,134 \pm 237$ & $3.87 \pm 0.08$ & $202 \pm 12$ & $2.98 \pm 0.04$ & $154 \pm 8$ \\
\hline \multirow{2}{*}{$>21.1$} & $\mathrm{I}(\mathrm{n}=31)$ & $4,465 \pm 192 * * *$ & $3.73 \pm 0.05$ & $168 \pm 9$ & $3.00 \pm 0.02$ & $134 \pm 6$ \\
\hline & II $(n=17)$ & $4,429 \pm 349$ *** & $3.80 \pm 0.09$ & $171 \pm 16$ & $2.94 \pm 0.04$ & $136 \pm 14$ \\
\hline
\end{tabular}

The cows with the age at the first fruitful insemination of 21.1 months had the lowest milk yields, compared with the cows with an earlier age at the first fruitful insemination - 4,465 $\mathrm{kg}$ in the cows with easy calving, and 4,429 $\mathrm{kg}$ in the cows with troubled calving, which was veraciously inferior to the cows in respective subgroups with the age at the first fruitful insemination of 15.117.0 months by $1,174 \mathrm{~kg}$ and $1,979 \mathrm{~kg}(\mathrm{P}>0.999)$.

The highest fat content was registered in the heifers with easy calving in the age at the first insemination up to 15 months $4.06 \%$; they were superior to the animals in all other groups.

The yield determines the amount of milk fat; the significantly higher milk fat content - $257 \mathrm{~kg}$ - was veraciously obtained from the cows with the milk yield of $6,408 \mathrm{~kg}$ in the second subgroup with the age at first insemination from 15.1 to 17.0 months with troubled calving. Lower milk fat content was registered in the cows with easy calving, the milk yield of $4,465 \mathrm{~kg}$ and low content of fat in milk - 3.73\%, but with later age at the first insemination - over 21.1 months.

Comparative characteristic of the mass fraction of protein in the milk revealed no significant differences. In terms of the amount of milk protein $(187 \mathrm{~kg})$, cows with troubled calving from the second subgroup were the best.

In their research, the authors considered one of the reasons that hindered milk production, namely, duration of the service period (Table 3). Cows' distribution into subgroups according to the duration of the service period (the first subgroup - up to 60 days, the second group - 61 to 90 days, the third group - 91 to 120 days, and the fourth group - 120 to 121 days and more) has shown that, given the fact that the duration of pregnancy in the cows of all the groups was in the range of 273 to 276 day, and the duration of the service period was about 90 days, one calf per year could be obtained from each cow.

Comparative analysis has shown that after troubled calving most cows $(n=72)$ needed over 121 days to restore before another fruitful insemination. In the animals that, despite troubled calving, had a relatively short service period from 61 to 90 days, the maximum milk yields of $6,206 \mathrm{~kg}$ were registered; however, such cows amounted to only $6.2 \%$ of the total number of cows with troubled calving $(n=6)$, and no veracious differences had been established in subgroups.

Table 3: Productive qualities of cows with different calving, depending on the duration of the service period

\begin{tabular}{|c|c|c|c|c|c|c|}
\hline $\begin{array}{l}\text { Duration of the } \\
\text { service period, days }\end{array}$ & Group & milk yield, $\mathrm{kg}$ & \begin{tabular}{ll} 
& \multicolumn{2}{c}{ Milk yield for } \\
mass fraction of \\
fat, \%
\end{tabular} & $\begin{array}{l}305 \text { days of the firs } \\
\text { amount of milk } \\
\text { fat, } \mathrm{kg}\end{array}$ & $\begin{array}{l}\text { lactation } \\
\text { mass fraction of } \\
\text { protein, } \%\end{array}$ & $\begin{array}{l}\text { amount of milk } \\
\text { protein, } \mathrm{kg}\end{array}$ \\
\hline Up to 60 & $\mathrm{I}(\mathrm{n}=45)$ & $4,596 \pm 179 * *$ & $3.86 \pm 0.06$ & $179 \pm 8$ & $2.95 \pm 0.02$ & $136 \pm 6$ \\
\hline \multirow{2}{*}{$61-90$} & $\mathrm{I}(\mathrm{n}=91)$ & $5,192 \pm 155^{*}$ & $3.92 \pm 0.04$ & $206 \pm 7$ & $2.97 \pm 0.02$ & $155 \pm 5$ \\
\hline & II $(n=6)$ & $6,206 \pm 544 * *$ & $3.75 \pm 0.10$ & $234 \pm 24$ & $2.91 \pm 0.09$ & $181 \pm 18$ \\
\hline \multirow{2}{*}{$91-120$} & $I(n=55)$ & $5,724 \pm 178$ & $3.80 \pm 0.04$ & $218 \pm 7$ & $2.92 \pm 0.02$ & $168 \pm 6$ \\
\hline & II $(n=18)$ & $5,259 \pm 301$ & $3.98 \pm 0.10$ & $212 \pm 15$ & $2.99 \pm 0.04$ & $158 \pm 10$ \\
\hline \multirow{2}{*}{ Over 121} & $I(n=70)$ & $5,876 \pm 172 * *$ & $3.84 \pm 0.04$ & $227 \pm 8$ & $3.00 \pm 0.03$ & $177 \pm 6$ \\
\hline & II $(n=72)$ & $5,513 \pm 185^{* *}$ & $3.80 \pm 0.05$ & $210 \pm 8$ & $2.96 \pm 0.03$ & $163 \pm 6$ \\
\hline
\end{tabular}

Milk yield in the cows with easy calving and short service period in the first sub-group was significantly lower by $1,280 \mathrm{~kg}$ $(\mathrm{P}>0.99)$ than in those with the same form of calving, but with the service period exceeding 121 days. In terms of the milk yield, they were also inferior to the cows with the duration of the service period from 61 to 90 days with both easy calving (difference of $596 \mathrm{~kg}$ ) and troubled calving $(6,206 \mathrm{~kg}$ vs $4,596 \mathrm{~kg}$ ) (difference of $1,610 \mathrm{~kg})(\mathrm{P}>0.99)$

A certain difference in the fat content in the milk has been found. Cows with the duration of the service period from 91 to 120 days had higher fat content in the milk - 3.98\%, and cows with troubled calving and the service period from 61 to 90 days had the low mass fraction of fat $-3.75 \%$.

\section{Conclusion}

Thus, milk yield in the cows with troubled calving is higher than in those with easy calving. The optimal age at the first fruitful 
insemination is the period between 15.1 and 17.0 months with the maximum milk yield during the first lactation of $6,206 \mathrm{~kg}$.

\section{Suggestions}

During the breeding work at JSC SF Povadino, the quality indicators of black-motley cows' milk productivity with different forms of calving should be considered.

\section{References}

[1] Volgin V., Vliyanie rosta i razvitie telyat na buduschie udoi, The influence of the calves' growth and development on consequent milk yields],/ V. Volgin, O. Vasilieva, Animal breeding in Russia, No. 4, 2011, pp. $23-25$

[2] Nardid A. V., Selektsionnie aspekti sovershenstvovaniya korov cherno-pestroi porodi po produktivnim i tehnologicheskim priznakam v usloviyah promishlennih ferm, Breeding aspects of improving black-motley cows by the productive and technological characteristics in the conditions of breeding farms, Cand. of Agricultural Sciences: 06.02.07, 06.02.10, Nardid Andrey Vasilievich, Nemchinovka, 2011, p. 120

[3] Nekrasov, A., Molochnaya produktivnost korov-pervotelok golshtinskoi porodi v zavisimosti ot viraschivaniya i sezona otela, Milk yields of Holstein heifers depending on the breeding and the calving season, A. Nekrasov, N. Popov, N. Nekrasovs, et al., Glavny Zootekhnik, No. 2, 2014, pp. 8-13.

[4] Novotolskaya, O. P., Pokazateli vosproizvoditelnoi sposobnosti airshirskih korov raznogo proishozhdeniya, Indicators of reproductive ability in Ireshire cows of various origin, P. O. Novotolskaya, A Y. Kozlovskaya, A. A. Leontyev, T. I. Skoptsova, V. Y. Kozlovsky, Agrarian Bulletin of the Urals, No. 1 (119), 2014, pp. 47-50. Chomaev, A. M. Vliyanie zhivoi massi i vozrasta telok pri pervom osemenenii na ih molochnuyu produktivnost, The effect of the live weight and the age of heifers at first insemination on their milk production, M. A. Chomaev, M. Tekeev, I. Kambiev, Dairy and beef cattle breeding, No. 3, 2010, pp. 11-13 